\title{
The Impacts of Zero-Tolerance Policy Towards Illegal Latin American Immigrants Under Donald Trump's Administration 2018
}

\author{
M Mardialina ${ }^{1}$, R A M Nagib ${ }^{2}$ \\ ${ }^{1,2}$ Universitas Mataram, West Nusa Tenggara \\ ${ }^{1}$ mala.mardialina@unram.ac.id, ${ }^{2}$ rimangb@gmail.com
}

\begin{abstract}
Illegal immigration has been one of America's ultimate problems, where various efforts were done to decrease the amount of illegal immigrants crossing the Southwest Border. Zero Tolerance Policy, as one of the efforts, was implemented under Donald Trump's administration, but unfortunately has problematic actions and results to combat illegal immigrants. The researchers assumed three justifications to analyze the background of policy-making process, limiting the scope into illegal Latin American immigrants. This research uses qualitative method through library research study to accommodate the required sources. The result of this paper are the impacts on the implementation of the policy such as 1) Legal Issues and Human Rights Violations; 2) Devaluation of the American Dream, 3) Psychological Effects.
\end{abstract}

Keywords: Zero Tolerance Policy, Donald Trump, Illegal Immigrants

\section{INTRODUCTION}

Illegal immigrants, as seen through its presence in the United States are resulted by the restricted amount of people aiming for U.S. residency and legal migration. Since thousands of people apply for migration yearly, the U.S. contains and imposes a series of complex preferential immigration laws. Favorable treatment is given to those with close ties to legal immigrant or resident of the U.S., skillful and sponsored people or approved as qualified refugees, despite long waiting period of visa. The case therefore provides an issue regarding U.S. border policy and sets a restricted quota system, albeit being renowned as the nation of immigrants. The U.S. government has attempted to provide proper regulation, but illegal immigrants still choose to defy the laws and settle unlawfully with the number reaching 11.3 million people by 2017. This phenomenon is not new, but deemed to be a major national protection problem by its citizens. Most undocumented immigration is driven by three factors including labor demands, unequal population growth and unemployment rates and limited visa availability[1].The U.S. Customs and Border Controls reported that in 2017, there are an estimated amount of 40,300[2] people illegally passing from Mexico without adequate documents, through the Southwestern border which divides the U.S. and Mexico[3]. These illegal immigrants mostly arrive from Latin American countries, topped by Mexico and Central American countries.

The current level of illegal immigration flows is dangerous according to those who perceive so. Illegal immigration, throughout history, has only increased resentment and skepticism among locals towards the government regarding the flow of immigrants, which 
only incited border security and immigration management; especially to promote national security interests. The government, alongside with multiple head of states, had different efforts in combating illegal immigration, most recently through Donald Trump's Zero Tolerance policy. The $45^{\text {th }}$ president of the United States had announced a more aggressive series of policies in his early days of presidency, where one of them is aimedat restricting or even prohibiting the stream of illegal immigration and to give a detterent effect on future illegal trespassers. The initial outlook of the policy seems biased on one specific group, while albeitly showing favoritism to other groups, indicating that there are justifications which provide the ability of Donald Trump to sign the policy and thus implementing it. What consitutes the formulation of this policy and its impacts should be analyzed further using a constructivist approach, which believes in a socially constructed notions of individual, states and world.

Based on the background above, the study aims to analyze the impacts of zerotolerance policy towards illegal Latin American immigrants under Donald Trump's administration, particularly in the year 2018. Other objectives aimed to be answered include explaining zero-tolerance policy and its implementation and describing the justifications of zero-tolerance policy.

Furthermore, this study is carried out within the results of the previous conducted studies, used as a comparison and study material.A report analysis conducted by Kandel (2018) on The Trump Administration's "Zero Tolerance" Immigration Enforcement Policystated that the policy was implemented in efforts to decrease the amount of illegal immigrants (alien) into the U.S. from primarily unstable nations (Mexico and Central American nations).It aims to prosecute all illegal immigrants crossing the U.S.-Mexico, may they be asylum seekers or those with underaged children. Similar to the recent study, the act of prosecuting illegal immigrants under previous adminstrations were found to be infrequent. Through guidelines, adult alien criminally prosecuted in the ports of entry should be detained, where children are detained according to various Agreements and Acts and kept in detention for no more than 20 days. Another point to address from this report refers to the amount of family apprehended in the southwest border, confirming the double increase in Trump's administration as compared to the preceedings[4].Theoritically, Madsen's (2015) thesis on EUs Immigrations Politic: The development of common policy towards illegal immigration in the EUuses constructivism to explain and analyze EU's immigration policy, where variables central to the theory are connected to the EU's principles. The thesis also states the importance of institution and norms which reflects the actions of key actors in decision-making processes and determining their foreign policies. Furthermore, a constructed security aspect such as "threat" towards immigrants (legal or illegal) is explained in detail, which is in convergence with the needs of this paper[5].

As far as this paper was made, there are no available researches found which explicitly explains about this paper's title.

\section{RESEARCH METHOD}

The study uses qualitative approach, examining the causal relations between actions and consequences as well as descriptive analysis. Secondary data dominates the study, but is able to accommodate the needs of the research. 


\section{RESULTS AND DISCUSSION}

The purpose of this section is to analyze the consequences of the policy based on the data obtained from preceding researches. Before embarking into further analysis, the writer aims to highlight the importance of defining and conceptualizing two key terms to avoid misconceptions as well as provide a systematic understanding under the political spectrum.

By definition, illegal immigration is the process by which people unlawfully settle in their destination countries, either due to visa expiration or illegal crossing[6]. Each country has their immigration policy; including limited quota-system, strict entry criteria and resources needed in controlling illegal immigration. Illegal immigration could also trigger unforeseen social issues[7]. When speaking about illegal immigrations' relations with affected social issues, constructivism is one of the most applicable theories to answer why a certain problem might be exaggerated in comparison to others. Deriving from constructed norms and values which results in experience or agreement, constructivism corresponds to Donald Trump's ban on illegal Latin American immigrants, where the so called Zero Tolerance policy is dependent on human agreement on its existence, and are taken for granted. Policies are created from these constructed experiences, through common agreement they put constraints on action and thereby influence the way in which actors act. Government institutions and legal procedures also play an important role in justifying the appropriate behaviour in relation to different subjects. The rules, norms and values constituted around the situation of Zero Tolerance policy which is circled around illegal latin immigrants, and separating family members are agreed upon in its own right, where the rules set up provide a causal linkage between the way a situation is appropriately treated and the consequences of this treatment (as a strengthening of border control measures due to a perceived threat of immigrants)[5].Constructivism provides two variables which support the existence of the theory, through common identity and common understanding. Common Understanding, or also known as Intersubjective Understanding is derived from perceptions, norms, values, and ideas, where these factors can be accessed or understood by two or more minds-alike[8].

The justifications of the anti-immigrant sentiment were derived through the history of European colonialization of the Americas from the infamous Gold, Gospel and Glory motto. Glory, to be precise, symbolizes the eminence of Christianity and its holy book, the Bible. Glory could also be traced back to The Book of Genesis in the Old Testament, which recorded a story of Noah (Prophet) cursing the descendants of Ham's son as slaves to Shem and Japheth. In modern times, the interpretation of the descendants would be: Ham (Africans), Shem (Arabs), and Japheth (Europeans)[9]. This common understanding of "white superiority" created what is known as common identity, which we can physically see from race, language, and skin color[10]. Subsequent to anti-colored people sentiment, the antiLatino discrimination can be traced back since the end of Mexican-American War. Since annexing more than half of Mexico's land into the United States, the locals followed citizenship changes. Apart from that, many Mexicans were also encouraged to emigrate from Mexico to the U.S. because of cheap labour demands, where the anti-latino sentiment grew along with immigration. The sentiment resulted into three consequences: the creation of segregated laws, by forbidding Latinos to enter 'white' establishments, perpetuate negative stereotypes such calling racial slurs and intensify violence. Any features related to that of Latinos - such as skin color, hair or language - is used as a tool of discrimination, although these Latinos were also critical to the U.S. economy. Great Depression was another event which spiked unfathomable hatred by white Americans towards Latin Americans (mostly Mexicans), often accusing the latinos and other foreigners of stealing 
American jobs as the stock market tanked and unemployment grew. As an example of these sentiments, Mexican-Americans were not allowed to accept charitable aids. [11]. A final point to add refers to the religious scriptures of Christianity, where a chapter of the Bible's New Testament (Romans 13) is used to justify white supremacy and whitechristian nationalism[12]. It spreads a dangerous notion of his legitimacy, as the highest level of government, to continue validating his racist antics because it is encouraged and will eventuallycreate a common belief within his followers. Racial stereotypes is prevalent during his campaign, where he openly showed his disdain for POCs (person of color), by calling Mexican immigrants "criminals" and "rapists"[13]. In short, the outcome of racist, biased and aggressive policies are constructed by a common agreement and is therefore a choice.

Shifting towards the legal aspect of the issue, the policy is not entirely original, which picked up its roots from preceding administration's laws. First, the Clinton Administration'sFlores Settlementin 1997only allow unaccompanied minors caught in the border to be held for 20 days and released back to their respectable guardians. Second, Bush Administration'sTrafficking Victims Protection Reauthorization Actin 2008that children from non-neighboring countries to be turned to Department of Health and Human Services within three days for resettlement. Third, Obama Administration's 9th U.S. Circuit Courts of Appeals in 2016 specify that children should be taken from their parents with regard to their safety. It further enacted the family detention centers where families await trial results, but didn't clarify whether parents and children will be released together. Detention centers violating the Flores agreement should release families together. Furthermore, Department of Homeland Security (DHS) subsequently implies that the policy will take effect under circumstanceswhen (a) DHS cannot assess the family relationship, (b) DHS confirms that a minor might be in danger with the parent or legitimate guardian, or (c) the parent or lawful guardian is alluded for criminal indictment[4].

The implementation of the policy was created under the Memorandum for Federal Prosecutors along the Southwest Border and instructed United States Attorney's Offices along the border to criminally prosecute anyone who enters unlawfully (even asylum-seekers) was officially called to be adopted on $6^{\text {th }}$ April. DHS refers any illegal border crossing to Department of Justice (DOJ) for prosecution. As stated above, this policy is no different from the prior ones, except those separations were phenomenal in light of the fact that the strategies didn't methodically target first time guilty parties for illegal crossing and made special cases for adults crossing with children. In fact, a series of institutional process should be passed before enforcing separation as the best alternative choice, as instructed by congress to DHS[14]. In facilitating the policy, the process is simplified into the following. First, prosecutors and immigration are sent to solve the cases. If a family is caught when crossing illegally in any entry port, then the Zero Tolerance Policy orders the U.S. Customs and Border Protection (CBP) refer all illegal adults to DOJ for criminal indictment. If childrens are present during the apprehension, they are separated from their adults and transferred to the custody of Office of Refugees Resettlement (ORR), in which kids live under agencysupervised and state-licensed shelters according to Trafficking Victims Protection Reauthorization Act(TVPRA). If possible, the ORR will either temporarily place the children with relatives, legal sponsors or foster care[4]. The government's position implied that the prosecuted parents are required to serve time in criminal custody (prosecuted and potentially deported). The children are prohibited to go to jail with their parents due to the rules, which systematically placed them in either criminal or immigration detention and proved the separations were the logical result[15]. 
Statistically, results have showcased the highpercentage of family unit apprehensions that happened during Trump's Zero Tolerance policy in the fiscal year of 2018, as compared to previous years. This suggests that vulnerable birth place conditions (mostly immigrants from Honduras, El Salvador and Guatemala) caused the $60.3 \%$ increase. Despite Trump's aggressive policy, FY2018 has never before experienced such dramatic increase in apprehension, suggesting that either the policy is weak or illegal immigrants were not aware when taking the journey. Similarsource showed the accumulated amount of family units apprehended, reaching to 107,212 people in May (658 children from 638 adults) which contributed to $27 \%$ increase from the previous years. Subsequently, DHS announced that 1,995 children have been separated from their parents between April and May, and 2,342 children between May and June [4].

Consequences of this policy should also be calculated, or else the influx of negative impacts will be unavoidable and uncontrolable. Unsurprisingly, the negative impacts outweigh the rest, ranging from laws without proper interpretation and conduct, devaluation of the American Dream and psychological effects to victims of the policy. To start, the Trump government does not differ between illegal entry and reentry, even though both are federal misdemeanor and punishable according to the convicted felonies. There is no law by Congress or any other body which requires family separation during the prosecution process. The deliberate separation of children from their parents is a strategic decision and choice by the administration. In fact, various efforts are made to condemn this policy, ranging from local to international organizations. The American Civil Liberties Union filed a lawsuit which challenged the Trump administration's family separation policy, where the plaintiffs' pointed several alleged violations such as(a) the right to seek protection as an asylum, where asylum is synonymous to refugee status and the U.S. immigration states that anyone can apply for asylum regardless of their immigration status, meaning that even illegal immigrants can apply[16], (b) according to the 1951 Refugee Convention, the policy violates a provision where a state should not punish refugees due to their illegal entry. The Fifth Amendment emphasizes the term due process, where it is comprehensively deciphered as the privilege to be dealt with reasonably, proficiently and effectively by the administration of justice[17], [18]. The policy violates the immigrants' rights to keep their family by proper due process. The violations under the policy follows the scheme where (a) immigration authorities separate families without proof that the parents were inappropriate for their children, even though both parents and children have fundamental liberty in the care, custody and control of each other and (b) parents deprived from their rights of due process or proper court hearing. Since they are within the U.S. territory, they are the future citizens of the U.S., thus are protected by the Fifth Amendement [19]. Furthermore, the U.S. ratified the International Covenant on Civil and Political Rights in 1992, which clearly mandates the government should treat the people, in this case the illegal immigrants - in arrest, detainment or imprisonment -as humanely as possible with respect to natural pose of human dignity. Another consistent violation to be accountable is the administration's' absence of giving appropriate and clean facilities in detainment which are damaging for kids[20]. Trump was also not hesitant to blame Democrats for his own administration's policy, claiming that it was made from the Democrats law and given to the federal government to implement[21].

Second, America has always been refered as the Promised Land for everyone who believes in it, and serves as a land to renew one's life. It is also related to the American Dream, which describes the dream of the every man and woman (natural-born and foreignborn) of land of opportunity. It is identified as the chance to climb the social ladder based on their natural capacities and accomplish quality goods and services despite prior diverse 
backgrounds [22]. Rooting from liberalism, the term itself acts as a fundamental value in shaping the modern American social life, and pushed its citizens to pursue unimaginable feats and discoveries in various fields. Regardless of one's social class, the American Dream was intended to consistently wind up with more than what one began with, provided that there are many opportunities to pursue individual interests[23]. Unfortunately, the Europeans - now white americans, interpreted this notion as their own homogenous goal, and excluding other racial groups (i.e. slavery), which results in referring that the "american dream" is only an illusion for minority groups in the U.S. Illegal immigrants who dream of equal social order and opportunites which they couldn't achieve in their homeland, have to go through obstacles of discrimination and racism from the domineering group[24]. Some perceived this notion is too "old" to be applicable in today's time, since Trump seems to close the "nation of immigrants" doors from the immigrants themselves through strict border patrols and policies. It rather seems to be an effort to drive out minority groups, by fearing, prosecuting and providing less job opportunities, as an approach to diminish rivalry for jobs or limit aid funds for conservative whites, inwhich all these devaluates the American Dream. These immigrants believe the American Dream yet they are deprived from the simplest form of basic needs. Despite the continuous negative perceptions towards them, these immigrants are more willing to push themselves into the American society, where small changes in their lives can be interpreted as a small step towards their ultimate american dream.

Apart from the dream, mental health issues highly impacted vulnerable and traumatized immigrants, may it be children or parents. Differences in conditions and attitudes trigger trauma, memory loss, stress, anxiety and fear, especially separated families who have previously developed a close bond [25]. Adults also experience psychological problems and even damages, including high-levels of anxiety and depression. Trauma from homeland violence added to the separation policy triggered self-harm and suicidal attempts[26], [27].

\section{CONCLUSIONS}

The implementation of Zero Tolerance policy was met with many criticisms and backlashes from various corners. The Trump administration is assumed to use the mentioned justifications to combat illegal immigrants, namely Latin American immigrants, along with the efforts to slowly drive out immigrants. The implementation is not without effects. Hundreds to thousands of children and their parents suffer from unimaginable psychological damages of this policy, ranging from depression, anxiety to suicidal thoughts. Although the executive order was signed to discontinue the policy and continue other methods of the same goal, it will always leave a big scar on the victims, where this situation is almost reminded of the Holocaust. It also leaves a larger question unanswered, whether the aimed deterrent effect has succeeded or reversely only increases the locals and immigrants' resistance.

\section{REFERENCES}

[1] D. S. Massey, "The Truth about Undocumented Immigration," Scholars Strategy Network, 2011. [Online]. Available: https://scholars.org/brief/truth-aboutundocumented-immigration. [Accessed: 10-Dec-2019].

[2] L. Qiu, "Border Crossings Have Been Declining for Years, Despite Claims of a 'Crisis of Illegal Immigration," The New York Times, 2018. [Online]. Available: https://www.nytimes.com/2018/06/20/us/politics/fact-check-trump-border-crossingsdeclining-.html. [Accessed: 10-Dec-2019]. 
[3] W. Dudley, Ed., Illegal Immigration: Opposing Viewpoints. San Diego: Green Haven Press, 2002.

[4] W. A. Kandel, "The Trump Administration's 'Zero Tolerance' Immigration Enforcement Policy,” 2018.

[5] L. L. Madsen, "EUs Immigrations Politic: The development of common policy towards illegal immigration in the EU," Aarloborg University, 2011.

[6] A. Gatt, "Illegal Immigration and Its Effect on Poverty," Malta, 2008.

[7] "Immigration Law," Law Teacher, 2018. [Online]. Available: https://www.lawteacher.net/free-law-essays/immigration-law/immigration-law.php. [Accessed: 10-Dec-2019].

[8] A. E. Hara, Pengantar Analisis Politik Luar Negeri: Dari Realisme sampai Konstruktivisme. Bandung: Nuansa Cendekia, 2011.

[9] "What is the biblical account of Shem, Ham, and Japheth?," GotQuestions, 2016. [Online]. Available: https://www.gotquestions.org/Shem-Ham-Japheth.html. [Accessed: 10-Dec-2019].

[10] M. A. Widmer and B. M. Erickson, "Understanding American Identity: An Introduction," Naval Postgraduate School, Monterey, 2017.

[11] E. Blakemore, "The Brutal History of Anti-Latino Discrimination in America," HISTORY, 2018. [Online]. Available: https://www.history.com/news/the-brutalhistory-of-anti-latino-discrimination-in-america. [Accessed: 10-Dec-2019].

[12] T. I. Burton, "White House: it's 'biblical' to take migrant children from their families," $\quad$ 2018. [Online]. Available: https://www.vox.com/2018/6/15/17467818/bible-verse-white-house-immigrationracism-romans-13. [Accessed: 10-Dec-2019].

[13] M. E. Locke, “The Barrabas Legacy: Race and Racism in Trump's America,” Juniper Publ., vol. 1, no. 5, pp. 00104-00105, 2018.

[14] "Family Separation Policy: What You Need to Know," PennState Law, 2018. [Online].

Available: https://pennstatelaw.psu.edu/sites/default/files/documents/pdfs/Immigrants/Family Separation Policy Factsheet June 2018.pdf. [Accessed: 10-Dec-2019].

[15] “Q\&A: Trump Administration's 'Zero-Tolerance' Immigration Policy," Human Rights Watch. [Online]. Available: https:/www.hrw.org/news/2018/08/16/qa-trumpadministrations-zero-tolerance-immigration-policy. [Accessed: 10-Dec-2019].

[16] L. Mancheno, "Analysis: How the asylum process works, and how it needs to change," CBS News, [Online]. Available: https://www.cbsnews.com/news/asylum-seekers-in-us-how-process-works-needs-tochange-analysis/. [Accessed: 10-Dec-2019].

[17] G. Frazee, "What constitutional rights do undocumented immigrants have?," $P B S$, 2018. [Online]. Available: https://www.pbs.org/newshour/politics/what-constitutionalrights-do-undocumented-immigrants-have. [Accessed: 10-Dec-2019].

[18] “The Right to Due Process," Icelandic Human Rights Centre. [Online]. Available: http://www.humanrights.is/en/human-rights-education-project/human-rights-conceptsideas-and-fora/substantive-human-rights/the-right-to-due-process. [Accessed: 10-Dec2019].

[19] A. Torres, "Trump's Zero-Tolerance Immigration Policy and Family Separation: A Deterrence Policy Gone Wrong," UIC John Marshal Law Review, 2018. [Online]. Available: https://lawreview.jmls.uic.edu/trumps-zero-tolerance-immigration-policyand-family-separation-a-deterrence-policy-gone-wrong/. [Accessed: 10-Dec-2019]. 
[20] J. Davis, "Trump's 'zero-tolerance' immigration policy violates human rights laws Business Insider," Business Insider, 2018. [Online]. Available: https://www.businessinsider.com/trumps-zero-tolerance-immigration-policy-violateshuman-rights-laws-2018-6/?IR=T. [Accessed: 10-Dec-2019].

[21] D. Jackson, "Donald Trump blames Democrats for his family separation policy," USA Today, $2018 . \quad$ [Online]. $\quad$ Available: https://www.usatoday.com/story/news/politics/2018/06/19/donald-trump-blamesdemocrats-his-family-separation-policy/713499002/. [Accessed: 10-Dec-2019].

[22] C. Dermo, "The American Dream: A Theoretical Approach to Understanding Consumer Capitalism," Sociol. Imagin. West. Undergrad. Sociol. Student J., vol. 3, no. 1, p. 1, Apr. 2014.

[23] K. D. Wilson, "The American Dream: In the Age of Diminished Expectations," Georgetown University, 2013.

[24] J. L. Del Cid, "The American Dream: An Illusion or Reality for Latino Immigrants," Liberty University, 2011.

[25] A. Fagan, "APA Urges Trump to Change Immigration Policy | Psychology Today Australia," Psychology Today, 2018. [Online]. Available: https://www.psychologytoday.com/au/blog/brainstorm/201806/apa-urges-trumpchange-immigration-policy. [Accessed: 10-Dec-2019].

[26] N. Einbinder, "How Trump's Family Separation Policy Has Affected Parents," PBS, 2018. [Online]. Available: https://www.pbs.org/wgbh/frontline/article/how-trumpsfamily-separation-policy-has-affected-parents/. [Accessed: 10-Dec-2019].

[27] K. Lorla, "Separating kids from parents at the border mirrors a 'textbook strategy' of domestic abuse, experts say - and causes irreversible, lifelong damage.," Business Insider, 2018. [Online]. Available: https://www.businessinsider.sg/psychologicaleffects-of-separating-immigrant-kids-and-parents-2018-6/?r=US\&IR=T. [Accessed: 10-Dec-2019]. 